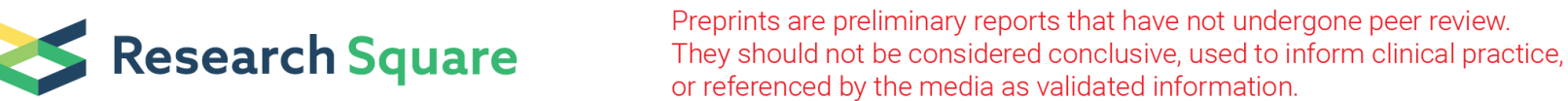

\section{How Creative Destruction Functions in Corporate Entrepreneurial Process: An Empirical Investigation of Schumpeterian Concept in Engineering Firms Setting in Pakistan}

Muhammad Zubair Alam ( $\square$ alam_zubair@hotmail.com )

Superior University Lahore https://orcid.org/0000-0003-4857-9245

Shazia Kousar

University of Jhang

Muhammad Rizwan Ullah

Government College University Faisalabad

Amber Pervaiz

University College Lahore

Research

Keywords: Creative destruction, Market orientation, Technical opportunity recognition, Corporate entrepreneurship, Schumpeter's entrepreneur

Posted Date: March 22nd, 2021

DOI: https://doi.org/10.21203/rs.3.rs-311356/v1

License: (c) (1) This work is licensed under a Creative Commons Attribution 4.0 International License.

Read Full License

Version of Record: A version of this preprint was published at Journal of Innovation and Entrepreneurship on January 25th, 2022. See the published version at https://doi.org/10.1186/s13731-022-00199-3. 


\section{Abstract}

Schumpeter's idea of creative destruction (CD) explains innovation functions in organisations. This paper investigates the $C D$ concept in engineering firms by explaining how technical opportunity (TO) transforms into corporate entrepreneurship (CE) actions once opportunities have a market orientation (MO). A survey conducted using a structured questionnaire with 132 managers in engineering firms in Pakistan.

Structural Equation Modeling (SEM) using Partial Least Square (PLS) approach has been used to analyse the data. Results reveal that MO and TO exerts a positive influence on CE. MO is the reason for the emergence of TO, which is exploited by CE's in engineering firms. CD intensifies the impact of MO on TO significantly. Opportunity recognition in engineering firms is distinguished and bounded by $\mathrm{MO}$ and technical viability. Engineering firms need to identify gaps in the market through naturally occurring obsolescence of products and services (CD) to create TO with appropriate MO. This study has revived a classical debate over opportunity recognition by proposing a CE model by incorporating external factors. The Schumpeterian opportunity recognition process and $C D$ have been explained for engineering firms that are distinguished from other types of firms. Kirznerian opportunity recognition view has also been debated to dialect Schumpeterian view.

\section{Introduction}

History has proved that businesses should be capable of rapid change, transformation, and innovation to fulfil the fast-changing marketplace's expectations. In this regard, corporations should improve their innovation capability, for which need for CE is evident (Lee \& Pati, 2017). Many academic researchers have analysed the concept of CE (Amore et al., 2013; Bai et al., 2016; Tian \& Wang, 2014). Various researchers also indicated entrepreneurship as the fundamental act supporting innovation (Amit et al., 1993; P Drucker, 1985). Innovation reverberates with Schumpeter and Redvers (1961) view, i.e., "entrepreneurship is the primary catalyst for innovation." This view is entirely concerned with entrepreneurial action as a crucial transformation mechanism. Echols and Neck (1998) indicated that CE is held to stimulate entrepreneurial action. CE uses management to embrace an interactive grace that promotes innovation (Barringer \& Bluedorn, 1999).

Schumpeter (2013) believed that innovations are the centre of economic change as they trigger the gales of "CD." Schumpeter (2013) defined CD as a process of industrial transformation where new opportunities are introduced to the market at the cost of existing ones. CE is a process through which an organisation is enthusiastic to abandon routine to seek new opportunities (Zampetakis \& Moustakis, 2010). Likewise, $\mathrm{CE}$ is liable for promoting the gales of $\mathrm{CD}$ within an organisation by inspecting new opportunities, resource acquisition, implementation, commercialisation, exploitation, and development of new products and services (Guth \& Ginsberg, 1990).

Various contextual factors, like uncertain influences or external jolts, impact individuals and firms' motivation to pursue new opportunities. For example, in pandemic COVID-19, individuals and firms seek opportunities in various market-relevant emerging requirements. Krueger Jr et al. (2000) emphasised the 
general business environment and its threats as an entrepreneurial opportunity process. Environmental threats and uncertainties are considered to emerge as a result of CD due to rapid technological changes in the market. In the case of technical products and services, as an outcome of engineering firms, the TO recognition process emerged due to ever and continually changing technology resulting in CD.

Schumpeter and Redvers (1961) believed that an entrepreneur requires TO for the development of new products. TO, technical skills, and distinctive technical capabilities positively affect the CE as it is the belvedere of knowledge that enables the up-gradation of the existing system or the development of the new system (Zahra et al., 1999). It is considered that TO usually arises from MO, which refers to the persistent search for opportunities. Any opportunity which arises in an organisation or market gives the path of exploitation by someone. It is an approach to business that identifies the customer's need and tries to develop the products according to their needs. $\mathrm{MO}$ is also perceived as a basis of innovation and competitive advantage (Barrett \& Weinstein, 2015).

J. Schumpeter (1934) and Peter Drucker (1985) advocate the emergence of entrepreneurial opportunity as a result of technological innovation. Sarasvathy et al. (2010) emphasised this opportunity recognition in known technological change under uncertain market demand. Also, a higher degree of technical knowledge about change influences on TO recognition. Technical knowledge to pursue TO will be influenced by market knowledge or MO. An important question arises, "Do engineering firms differ in opportunity identification approach?"

Academic researchers have worked on the relationship between MO and CE (González-Benito et al., 2009; Renko et al., 2009; Sciascia et al., 2006) and also found strong evidence of the relationship between entrepreneurial opportunity and CE (García-Morales et al., 2014). Still, the area of CE concerning TO is under discussion in academia, specifically in engineering firms. Therefore, the present study shifts the focus from the extensively researched area, i.e., the entrepreneurial opportunity to the less focused area, i.e., TO because employees in entrepreneurial engineering firms are always looking for a TO. Till now, in entrepreneurship literature, the relationship between TO and CE is very less focused. The indirect link between $\mathrm{MO}$ and $\mathrm{CE}$ (through TO) is also not established by existing researchers.

Furthermore, the CD's moderating role on the association between $\mathrm{MO}$ and $\mathrm{TO}$ is to be considered as the same has not empirically tested in the context of engineering firms. Therefore, the present study contributes to the current debate of $C E$ by empirically examining the missing link between $T O, M O, C D$, and $\mathrm{CE}$ in the context of engineering firms in Pakistan (shown in figure 1).

The present study significantly enhances the existing literature on CE in the engineering industry in Pakistan. This study offers a new approach for firms in the opportunity recognition process, which transforms from the inner organisational function of change (innovation) to look for gradual obsolescence of products and services in the market through the natural process of $C D$ in the opportunity creation process. 


\section{Literature Review And Hypothesis Development}

\subsection{Schumpeter's theory of innovation}

Joseph Alois Schumpeter is among one of the greatest economists who took part in the economic debate. His theory of innovation is the most distinctive contribution to economics (Hanusch \& Pyka, 2007). According to Schumpeter, innovations are the fundamental factor of economic competitiveness and are the centre of economic change as they trigger the gales of " $C D$ " (Schumpeter, 2013). Schumpeter defined $C D$ as a process of industrial transformation, which alters the economic structure from inside, i.e., through constant destruction of the old one and continued creation of a new one. Schumpeter believed that "entrepreneur" plays an essential role in the process of innovation as they make the possible implementation of new combinations in business in the form of new products, new markets, and new methods of production. The purpose of entrepreneurs is to transform the production process by exploiting the creation and opening of new sources of raw materials, or a new aperture for products, by rearranging a business. For this, the TO is considered an essential factor. By considering Schumpeter's view of innovation, i.e., the implementation of new combinations is an entrepreneurial activity, numerous researchers have observed that innovations play a crucial role in CE (Ireland et al., 2009; Schumpeter \& Backhaus, 2003). His theory provides a clear theoretical justification for the relationship between TO, CD, and $\mathrm{CE}$ and motivates us to work in the engineering industry framework in Pakistan. The present study extends Schumpeter's theory of innovation by incorporating the role of MO.

\subsection{Corporate entrepreneurship}

1. Schumpeter (1934) defined that entrepreneurs are the ones who carried out the new combinations in a business. He stated that "the entrepreneurial function is the vehicle of a continual reorganisation of the economic system" (pp. 155-156). The initial step to explain CE is to define those aspects of ENT that explicate to the CE. Covin and Slevin (1991) stated that CE depends on product modification, risk-taking tendency, and dedication. Jennings and Lumpkin (1989) defined CE as the extent to which new products are developed. CE comprises two types of phenomena, such as the development of new products within existing organisations and the restoration of the organisation through the revival of new ideas (Guth \& Ginsberg, 1990). It is perceived as an organisational process that transforms individual thoughts into corporate action (Chung \& Gibbons, 1997).

\subsection{Entrepreneurial and technical opportunity}

Opportunity recognition is defined as: "the process by which entrepreneurs see something that has the potential value" (Ardichvili et al., 2003)". Schumpeterian (creation) and Kirznerian (discovery) views are dialectics that are relevant to TO in engineering firms. Few researchers (e.g., Blaug, 2000) describe these views as complementary rather than opposing, but many scholars debated these views as opposing (Barney, 1991; Buenstorf, 2007). Kirzner (1997) advocates access to existing information while J. Schumpeter (1934) stressed acquiring new information in the market to recognise the entrepreneurial opportunity. The Discovery view of entrepreneurial opportunity recognition assumes that individuals and 
firms discover opportunities by recognising the value of new information instead of searching (Kirzner, 1997). The creation view assumes the possibility of innovative products and service by creating innovative opportunities through search (J. Schumpeter, 1934).

Where individual internal factors of organisation impact entrepreneurial opportunity recognition, various research studies have stressed the importance of external environmental factors (Singh, 2000). Accordingly, consumer economics, political action, social values, technology, and regulatory standards instigate firms and individuals to pursue the opportunity. Shane (2003) and J. Schumpeter (1934) have viewed entrepreneurial opportunity emergence as a result of social and demographic changes, political and regulatory changes, and technological changes.

\subsection{Market orientation and corporate entrepreneurship}

The foundation of corporate entrepreneurs is to create an environment that validates the innovative business capacity (Antoncic \& Hisrich, 2001; Goosen et al., 2002). CE retains business's strategic renewal, thus assuring its innovation and profitability (Drucker, 2007). Businesses have to participate in entrepreneurial action to work efficiently in competitive markets (Zimmerman, 2010). The linkage between $\mathrm{CE}$ and $\mathrm{MO}$ is perceived as the centre of business innovation and competitiveness (Barrett \& Weinstein, 2015; Karlin et al., 2010).

MO refers to the continuous search for market opportunities and consistent reaction strategies that facilitate the firms to improve their performance. MO occurs through the sequential process of intelligence generation, intelligence dissemination, and responsiveness of the firms (Kohli \& Jaworski, 1990). It is visualised as a direct connection between marketing and CE as the basis of the company's value creation (Barrett \& Weinstein, 2015). MO is an arrangement of openness, and receptiveness of market intelligence (Jaworski \& Kohli, 1996; Kohli \& Jaworski, 1990), which implies the exploitation of inventive things in response to market conditions (Narver \& Slater, 1990; Slater \& Narver, 1994). An efficient MO specifies a conviction to adjust to customers' unpredictable future needs (Atuahene-Gima et al., 2005) and thus improve the conservation of competitive strategies and initiates innovative inducements (Zachary et al., 2011; Zortea-Johnston et al., 2012).

Considering the importance of $\mathrm{MO}$, businesses researchers have started investigating the empirical relationship between $\mathrm{MO}$ and CE. For instance, the study of Barrett and Weinstein (2015) has shown a significant association between $\mathrm{MO}$ and $\mathrm{CE}$ as it provides the basis of innovation and competitive advantage. González-Benito et al. (2009) revealed a strong and positive relationship between MO and CE. Sciascia et al. (2006) indicated MO as an essential determinant of CE. A business should involve similar practical approaches to be successful in this vigorous era (Renko et al., 2009). The continuous search for market acquaintance demands maintaining an additional entrepreneurial alignment (Bojica et al., 2011). Therefore, the present study proposes that:

$\mathrm{H1}$ : $\quad \mathrm{MO}$ relates significantly and positively to $\mathrm{CE}$. 
Alsos and Kaikkonen (2002) defined the opportunity as the possibility of introducing new products. It is an essential concept in entrepreneurship as it is perceived as an ability of entrepreneurs to discover the solution of a problem (Chandler et al., 2002). An entrepreneur is always searching for an opportunity through which he can implement his ideas for developing new products or upgrading existing products. The existing literature of entrepreneurship has specified that the achievement of entrepreneurial opportunity can be divided into opportunity, identification, and exploitation (Choi et al., 2008; Eckhardt \& Shane, 2003; Shane, 2012; Shane \& Venkataraman, 2000; Williams \& Wood, 2015).

Different views (e.g., cultural-cognitive and economic) emerged to explain the entrepreneurial opportunity identification process. The economic view describes that opportunity exists in the environment as an objective phenomenon (Companys \& McMullen, 2007). As a result of this view, entrepreneurs are likely to recognise opportunities as a result of better prior knowledge (Shane \& Venkataraman, 2000; Shepherd \& DeTienne, 2005), being more alert (Gaglio \& Katz, 2001) and with better information (Hayek, 1945; Shane \& Venkataraman, 2000). These antecedents of opportunity recognition are useful after the gradual learning process (Dimov, 2002). The cultural-cognitive view describes the entrepreneurial opportunity as a subjective phenomenon in which individuals create opportunity. Accordingly, the entrepreneurial opportunity exists when created and recognised by firms or individuals (Companys \& McMullen, 2007, p. 305).

The present study, therefore, considers that entrepreneurial opportunity comes from the MO. MO refers to the persistent search for opportunities. Any opportunity which arises in an organisation or market gives the path of exploitation by someone. It is an approach to business that identifies the customer's need and tries to develop the products according to their needs. Schumpeter and Backhaus (2003) believed that an entrepreneur requires TO through which he can develop new products for which technical change is required. Technological change is an essential factor of entrepreneurial opportunity, which makes the possible allocation of resources in more productive ways of developing new products or upgrading existing products (Casson, 1995). According to Bhide (2003), about half of the founders of private companies (fortune 500) in the US indicated that change in technology or external factors was the reason for business initiation. Also, the increase in the technological change rate has resulted in a rise in entrepreneurial start-ups (Blau, 1987).

The present study shifts focus from the entrepreneurial opportunity to TO as CE's in engineering firms always look for a TO. The concept of TO is drawn from Schumpeter's theory of innovation. Schumpeter specified that opportunity requires the development of new knowledge that comes from technological change. García-Morales et al. (2014) empirically tested the relationship between technological change and CE and showed that technological change tends to increase CE. Therefore, the present study proposes that:

H2. TO relates significantly and positively to CE. 
H3. MO relates significantly and positively to TO.

\subsection{The mediating role of Technical opportunity}

For individuals why, when, and how people discover opportunities is adequately addressed in research (e.g., Shane \& Venkataraman, 2000), but especially for firms dealing with some engineering related products or services, opportunity recognition literature is scarce.

The present study contends that MO is the prime cause of the creation of TO's in engineering firms, which is identified and exploited through the firm's inner processes (CE). From the discussion above, it is proposed that TO, MO, and CE are interlinked. CE's in engineering firms are always in search of TO, which comes from MO. Till present, TO's mediating role on the association between $\mathrm{MO}$ and $\mathrm{CE}$ has not been tested empirically. Therefore, the present study proposes that:

H4. TO mediates the relationship between $\mathrm{MO}$ and $\mathrm{CE}$.

\subsection{The moderating role of creative destruction}

Various researchers stressed entrepreneurs to discover opportunities in the external environment, e.g., Drucker (1998). However, J. Schumpeter $(1934$, p. 65) suggests that it is the producer who initiates an economic change resulting education of consumers towards the adaptation of new things.

The present study proposes that $\mathrm{CD}$ intensifies the relationship between $\mathrm{MO}$ and $\mathrm{TO}$ as it plays a significant role in developing new opportunities. Opportunities usually come from the needs of customers. $\mathrm{MO}$ is an approach to business that identifies the customer's need and tries to develop the products according to their needs. It also becomes a means of the CD because once a consumer uses a product, then he/ she can be able to recommend that how this product should be improved, which provides a TO to the corporate entrepreneur in the process of product improvement. Thus, we hypothesised that

H5. CD intensifies the relationship between $\mathrm{MO}$ and TO.

The proposed research model from above-hypothesised relationships is as under:

\section{Methods}

Hypotheses formulation has been done after a review of the literature and linking CE antecedents with Schumpeter's historical breakthrough in entrepreneurial research. In lines with Wilson (2014), the deductive approach has been used to formulate hypotheses based on existing constructs' relationships.

\subsection{Sampling}


Data collection has been done from engineers on engineering or managerial roles working in private firms. Data collection has been done using convenience sampling to approach engineers from industrial sectors operating in Pakistan's different geographical areas. In entrepreneurship research, this type of non-probability sampling has often been used despite generalizability concerns (Alam, Bilal, et al., 2020; Krueger Jr et al., 2000; Munir et al., 2019). Online questionnaires link was sent to respondents after acquiring their consent to participate in the study. One hundred thirty-two responses included in the study. Responses of 81 male engineers (61\%) and 51 female engineers (39\%) form part of the study for analysis. 42 (32\%) engineers who form part of the study are from the textile industry, 29 (22\%) from automotive manufacturing, $36(27 \%)$ from power sector maintenance, and $26(19 \%)$ from the telecom engineering sector.

\subsection{Instrumentation}

Measurement scales of $\mathrm{MO}$ and $\mathrm{CE}$ have been adapted from existing literature as these latent constructs are well established in the literature. Scale for MO has been adapted from (Saraf et al., 2007). Sample items include "our philosophy of doing business is driven by the need of putting customers first." Hornsby et al. (2002) have developed a comprehensive scale to measure CE, which has been validated by Rutherford and Holt (2007) and Goodale et al. (2011). This 48 item Corporate Entrepreneurship Assessment Instrument (CEAI) used to measure five dimensions of CE as a second-order construct. CD as a concept has been specified by J. Schumpeter (1934); however, researchers have not used it as a construct to test entrepreneurial phenomenon or process. Scale for CD was developed for this study. Items of the scale include 1) new products replace the existing products in markets, 2) changing environment creates the need for new technologies and products, 3) many existing products in market become obsolete due to improved new products, and 4) creation of a products or service leads to the replacement of old ones. TO recognition construct is perceived as an equivalent construct to entrepreneurial opportunity recognition. From the engineering firms' perspective, TO recognition is similar to market need dictates of manufacturing and selling a product besides the technical possibility of manufacturing playing an important role in a particular engineering firm. In lines with the outline concept of TO recognition, the scale has been adapted from Park et al. (2017) to test the proposed hypotheses, which is taken as a second-order construct. 5-point Likert scale has been used to measure items of constructs.

\subsection{Data Analysis}

Since constructs used in the model are latent constructs with multiple items of measurement; hence, the multivariate technique SEM is most appropriate for this study. SEM is a widely used approach (Alam et al., 2019; Alam, Kousar, et al., 2020) in management science and entrepreneurship based studies (Sarstedt, 2014). Covariance based and PLS are the two primary methods in SEM (Hair et al., 2019). In this study, PLS-SEM is used for data analysis as the research model is unique, and the sole purpose is the investigation of relationships at the theoretical level (Hair et al., 2019). PLS-SEM is appropriate due to 
small sample size requirements, level of measurement, friendly interface, and normality of data issues (Chin \& Newsted, 1999).

Through self-report scales, the data collection for independent and dependent variables was done at the same time, which could raise the issue of common method bias in study results. In lines with recommendations of Kock (2015), variation inflation factor (VIF) of constructs obtained to observe pathological collinearity, which could be used as an indication of contamination of data due to common method bias. The factor-level VIF values of constructs from full collinearity test were obtained, and all values were found lower than the threshold of 3.3. Hence, the model is free of common method bias (Kock, 2015, p. 7).

\section{Results}

\subsection{Measurement model}

The study employed confirmatory factor analysis (CFA) for first and second-order constructs to verify the interrelatedness of constructs in the hypothesised model. Few items from adapted scales were deleted due to low loadings, and only the required number of items from available scales have been included for analysis. The reflective measurement model's validity was determined by examining its internal consistency and the convergent and discriminate validities. The reliability of all reflective measures was computed by using composite reliability (CR) and Cronbach's a value. Values for each variable satisfied the recommended threshold level, which was above 0.7 (Fornell \& Larcker, 1981). Average variance explained (AVE) has been used to compute convergent validity. Items included for the measurement of constructs have loadings above the threshold value of 0.7 (Hair et al., 2016). The measurement model assessment results for first and second-order constructs comprising indicator reliability, internal consistency reliability, and convergent validity are presented in Table I. The Heterotrait-Monotrait ratio of correlations (HTMT) has been used to assess discriminant validity (threshold $<0.85$ ) of first and secondorder constructs (Henseler et al., 2015). The discriminant validity results for first-order constructs and second-order constructs are presented in Table II and Table III. Multi-collinearity issues were not there in data since VIFs were found less than 5 (Hair et al., 2011). The measurement model was found to be appropriate for the assessment of the structural model and further analysis.

\section{Table 1. Assessment of measurement model for first and second-order constructs}




\begin{tabular}{|c|c|c|c|c|c|c|c|}
\hline \multirow[t]{2}{*}{$\begin{array}{l}\text { Latent } \\
\text { variables }\end{array}$} & \multirow[t]{2}{*}{ Dimension } & \multirow[t]{2}{*}{ Items } & \multicolumn{2}{|c|}{ Indicator reliability } & \multicolumn{2}{|c|}{$\begin{array}{l}\text { Internal } \\
\text { consistency } \\
\text { reliability }\end{array}$} & \multirow{2}{*}{$\begin{array}{l}\begin{array}{l}\text { Convergent } \\
\text { validity }\end{array} \\
\text { AVE }\end{array}$} \\
\hline & & & $\begin{array}{l}\text { First - } \\
\text { order } \\
\text { loadings }\end{array}$ & $\begin{array}{l}\text { Second- } \\
\text { order } \\
\text { loadings }\end{array}$ & a & CR & \\
\hline \multirow[t]{3}{*}{ MO } & \multirow[t]{3}{*}{-} & MO_1 & 0.858 & \multirow[t]{3}{*}{-} & \multirow[t]{3}{*}{0.882} & \multirow[t]{3}{*}{0.926} & \multirow[t]{3}{*}{0.806} \\
\hline & & MO_2 & 0.91 & & & & \\
\hline & & MO_3 & 0.924 & & & & \\
\hline \multirow[t]{4}{*}{ CD } & \multirow[t]{4}{*}{-} & CD_1 & 0.879 & \multirow[t]{4}{*}{-} & \multirow[t]{4}{*}{0.88} & \multirow[t]{4}{*}{0.914} & \multirow[t]{4}{*}{0.727} \\
\hline & & CD_2 & 0.925 & & & & \\
\hline & & CD_3 & 0.884 & & & & \\
\hline & & CD_4 & 0.707 & & & & \\
\hline \multirow[t]{11}{*}{ TO } & \multirow{5}{*}{$\begin{array}{l}\text { Opportunity } \\
\text { discovery (OD) }\end{array}$} & OD_1 & 0.755 & \multirow[t]{5}{*}{0.917} & \multirow[t]{5}{*}{0.896} & \multirow[t]{5}{*}{0.923} & \multirow[t]{5}{*}{0.707} \\
\hline & & OD_2 & 0.88 & & & & \\
\hline & & OD_3 & 0.902 & & & & \\
\hline & & OD_4 & 0.795 & & & & \\
\hline & & OD_5 & 0.862 & & & & \\
\hline & \multirow{6}{*}{$\begin{array}{l}\text { Opportunity } \\
\text { creation (OC) }\end{array}$} & OC_1 & 0.795 & \multirow[t]{6}{*}{0.726} & \multirow[t]{6}{*}{0.838} & \multirow[t]{6}{*}{0.881} & \multirow[t]{6}{*}{0.554} \\
\hline & & OC_2 & 0.791 & & & & \\
\hline & & OC_3 & 0.693 & & & & \\
\hline & & OC_4 & 0.774 & & & & \\
\hline & & OC_5 & 0.757 & & & & \\
\hline & & OC_6 & 0.645 & & & & \\
\hline \multirow[t]{7}{*}{ CE } & \multirow{6}{*}{$\begin{array}{l}\text { Management } \\
\text { support (MS) }\end{array}$} & MS_1 & 0.811 & \multirow[t]{6}{*}{0.843} & 0.935 & 0.949 & 0.756 \\
\hline & & MS_2 & 0.896 & & & & \\
\hline & & MS_3 & 0.845 & & & & \\
\hline & & MS_4 & 0.911 & & & & \\
\hline & & MS_5 & 0.895 & & & & \\
\hline & & MS_6 & 0.856 & & & & \\
\hline & $\begin{array}{l}\text { Work discretion } \\
\text { (WD) }\end{array}$ & WD_1 & 0.765 & 0.86 & 0.784 & 0.85 & 0.537 \\
\hline
\end{tabular}




\begin{tabular}{|c|c|c|c|c|c|c|}
\hline & WD_2 & 0.792 & & & & \\
\hline & WD_3 & 0.768 & & & & \\
\hline & WD_4 & .0784 & & & & \\
\hline & WD_5 & 0.718 & & & & \\
\hline \multirow{4}{*}{$\begin{array}{l}\text { Rewards/ } \\
\text { Reinforcement } \\
\text { (RR) }\end{array}$} & RR_1 & 0.845 & \multirow[t]{4}{*}{0.911} & \multirow[t]{4}{*}{0.859} & \multirow[t]{4}{*}{0.9} & \multirow[t]{4}{*}{0.694} \\
\hline & RR_2 & 0.902 & & & & \\
\hline & RR_3 & 0.742 & & & & \\
\hline & RR_4 & 0.834 & & & & \\
\hline \multirow{4}{*}{$\begin{array}{l}\text { Time availability } \\
\text { (TA) }\end{array}$} & TA_1 & 0.727 & \multirow[t]{4}{*}{0.742} & \multirow[t]{4}{*}{0.76} & \multirow[t]{4}{*}{0.849} & \multirow[t]{4}{*}{0.596} \\
\hline & TA_2 & 0.838 & & & & \\
\hline & TA_3 & 0.815 & & & & \\
\hline & TA_4 & 0.669 & & & & \\
\hline \multirow{4}{*}{$\begin{array}{l}\text { Organisational } \\
\text { boundaries (OB) }\end{array}$} & OB_1 & 0.891 & \multirow[t]{4}{*}{0.903} & \multirow[t]{4}{*}{0.927} & \multirow[t]{4}{*}{0.946} & \multirow[t]{4}{*}{0.815} \\
\hline & OB_2 & 0.929 & & & & \\
\hline & OB_3 & 0.894 & & & & \\
\hline & OB_4 & 0.897 & & & & \\
\hline
\end{tabular}

Table 2. Discriminant validity (HTMT) for first-order constructs 


\begin{tabular}{|c|c|c|c|c|c|c|c|c|c|}
\hline & $C D$ & MO & MS & $\mathrm{OB}$ & $\mathrm{OC}$ & $O D$ & $\mathrm{RR}$ & TA & WD \\
\hline \multicolumn{10}{|l|}{$C D$} \\
\hline MO & 0.823 & & & & & & & & \\
\hline $\begin{array}{l}\text { Management support } \\
\text { (MS) }\end{array}$ & 0.081 & 0.053 & & & & & & & \\
\hline $\begin{array}{l}\text { Organisational } \\
\text { boundaries (OB) }\end{array}$ & 0.379 & 0.374 & 0.07 & & & & & & \\
\hline $\begin{array}{l}\text { Opportunity creation } \\
\text { (OC) }\end{array}$ & 0.102 & 0.057 & 0.703 & 0.091 & & & & & \\
\hline $\begin{array}{l}\text { Organisational } \\
\text { discovery (OD) }\end{array}$ & 0.416 & 0.397 & 0.08 & 0.547 & 0.092 & & & & \\
\hline $\begin{array}{l}\text { Rewards/ } \\
\text { Reinforcement (RR) }\end{array}$ & 0.541 & 0.527 & 0.084 & 0.653 & 0.155 & 0.752 & & & \\
\hline Time availability (TA) & 0.127 & 0.117 & 0.533 & 0.069 & 0.69 & 0.144 & 0.121 & & \\
\hline Work discretion (WD) & 0.181 & 0.141 & 0.137 & 0.163 & 0.172 & 0.116 & 0.133 & 0.142 & \\
\hline
\end{tabular}

Table 3. Discriminant validity (HTMT) after generating second-order constructs

\begin{tabular}{|lllll|}
\hline & CE & CD & MO & TO \\
CE & & & & \\
CD & 0.473 & & & \\
MO & 0.436 & 0.816 & & \\
TO & 0.795 & 0.692 & 0.646 & \\
\hline
\end{tabular}

\subsection{Structural model}

The study's proposed hypotheses $(\mathrm{H} 1-\mathrm{H} 5)$ were tested by the assessment of the structural model for higher-order constructs. Hypotheses testing has been done through examination of the significance of the relationships among constructs with path coefficients. For assessing the significance of path coefficients, the bootstrap resampling method in PLS has been performed (Chin, 1998).

Results indicate that $M O$ is positively associated with $C E(\beta=0.19, p<0.05)$, supporting $H 1$, TO is positively associated with $\mathrm{CE}(\beta=0.202, \mathrm{p}<0.05)$, supporting $\mathrm{H} 2$ and $\mathrm{MO}$ is positively associated with TO $(\beta=0.289, p<0.05)$, supporting H3. As proposed by Shrout and Bolger (2002), the bootstrap procedure was performed to verify the significance of indirect effects on the 5000 samples. This procedure provides a point estimate of the indirect effect at the $95 \%$ confidence interval $(\mathrm{Cl})$ through 
bootstrap approximation (MacKinnon et al., 2004). The indirect effect of MO on CE through TO (estimate $=0.059,95 \% \mathrm{Cl}=[0.015,0.082], \mathrm{p}<0.05)$ was significant as the confidence intervals did not include zero.

CD significantly moderates between $\mathrm{MO}$ and $\mathrm{TO}$ (estimate $=0.141,95 \% \mathrm{Cl}=[0.026,0.337], \mathrm{p}<0.05$ ). Figure 2 showed the nature of the moderating effect obtained through plotting values of unstandardised $\beta$ of moderating effect (CD), independent (MO) and dependent variables (TO). The plot shows, with a low level of CD, MO has less impact on TO. However, with the high level of CD, MO has a high impact on TO, hence, CD strengthens the positive effect of $\mathrm{MO}$ on TO.

\section{Discussion And Future Research Directions}

The purpose of this study was to investigate the CE process in engineering firms regarding insights about TO recognition. Further, this study also links the Schumpeterian opportunity creation concept of CD in MO and TO which influences CE.

This study has suggested a model incorporating Schumpeterian opportunity creation and CD concept to explain CE's emergence in engineering firms. Most CE research is limited to seeking antecedents in various contexts (Alam, Kousar, et al., 2020; Woo, 2018) as the phenomenon is still in the exploratory stage. This is perhaps due to various synonymous terms explaining similar phenomena like corporate venturing, strategic renewal, and intrapreneurship (Meyer \& Heppard, 2000). Also, the issue of the dependent variable in $\mathrm{CE}$ research restrict researchers to look for practical outcomes of $\mathrm{CE}$, which could be explained through a sound theoretical basis.

Since CE is an auxiliary in entrepreneurship research, the first step is to determine all CE studies' dimensions linked with entrepreneurship. Results suggest a positive relationship of $\mathrm{MO}$ with CE in line with previous research (Baker \& Sinkula, 2009; Barrett et al., 2012) on entrepreneurship relationships. Although previous research on the relationship between $\mathrm{MO}$ and $\mathrm{CE}$ was carried in various contexts (Ahmed, 2016), specific to engineering or technology firms, this relationship merits due focus.

The findings of this study confirmed that $\mathrm{MO}$ and $\mathrm{TO}$ are essential antecedents of $\mathrm{CE}$ in engineering firms. The TO recognition is somewhat considered equivalent to the entrepreneurial opportunity that required deliberation by academic researchers. This study suggests that the Schumpeterian concept of CD explains TO in engineering firms, and theoretical perspectives that have been investigated in other contexts need further empirical evaluation. J. Schumpeter (1934) and Shane (2003) viewed that technological development occurs well in suitable environmental conditions, and these also inspire individuals to seek opportunities. Additionally, findings also extend Lee and Venkataraman (2006) argument about the limitations of existing literature towards the importance of external context in opportunity recognition. Lee and Venkataraman (2006) assert that existing literature has emphasised more on individual factors that need to be considered along with external factors in the opportunity recognition process. The present study has considered only the external factors in the opportunity 
recognition process. Future studies could compare the individual and external factors in other contexts to investigate which (individual or external) explains opportunity recognition better. Previous research supports this study's findings on opportunity and CE results (Pech \& Cameron, 2006), and innovation and venture growth can be explained as a function of opportunity recognition (Sambasivan et al., 2009).

Although this study has investigated external factors in opportunity recognition to impact CE, opportunity recognition is a vast phenomenon, and $\mathrm{MO}$ is just one dimension of it. Future studies could consider established antecedents of opportunity recognition (nations' cultural and social characteristics) in similar contextual studies.

This study's results support the intensifying CD impact on MO and TO link in the proposed model. CD's impact on the proposed relationship provides empirical backing to Schumpeter's idea. Although Schumpeter's work has great significance in entrepreneurship literature, few researchers have identified limitations to his work on understanding entrepreneurship. Regardless of the famous phrase "CD," Schumpeter's work explains only the proceeding of novelty but failed to explain entirely new entrepreneurial creativity as his overall framework favours human will against the subjectivism of the human mind (Witt \& Foster, 1992). Schumpeter supports disruption of economic equilibrium by entrepreneurs to attain another one is the very idea of CD, contrary to Kirzner's (1973) approach of opportunity recognition and market equilibrium.

The proposed model contributes to the entrepreneurship literature in general and CE literature, specifically, in several ways. First, this model proposed another view to classical debate on the opportunity and distinguished entrepreneurial opportunity from TO in lines with Schumpeterian argument on technical innovation through invention. The debate on whether $C D$ creates market disequilibrium or equilibrium is the result of $C D$, which future researchers can view to explore the $C D$ phenomenon in depth. Also, whether $\mathrm{CD}$ as a phenomenon is useful in overall economic fabric from the capitalist or socialist point of view can be further examined. The proposed model adds elements to the concept and facilitates understanding of CE from opportunity and market antecedents.

Most innovative technological products are the outcome of technological breakthroughs in the field with a somewhat vague idea of its market acceptability (Bennett \& Cooper, 1979, p. 77). A technical breakthrough in any field is not necessarily bound to $\mathrm{MO}$ as market needs, and varied customer demands could simply fail an otherwise quality product (Kerby, 1972) because customers have their perceptions and needs about familiar things (Bennett \& Cooper, 1981). Also, only customer orientation will not be enough as getting closer to customers can also hinder innovation rather than its promotion (MacDonald, 1995). Hence, TO, if emanates from market demand (or MO), can initiate CE activity in engineering firms that could be contributory to the economy. MO of products is linked with existing products' overall status about whether current products match customer's expectations? CD will fill gaps where current market products are becoming obsolete due to new trends and emerging demands. This will stimulate TO recognition, and the results of this study empirically prove this important link for incorporation in existing theories to explain CE antecedents. 


\section{Conclusion}

In conclusion, $C E$ distinctions in engineering firms are to be taken from the Schumpeterian idea of $C D$, which seems less relevant in less technically oriented industries. TO recognition is the main driving force, which should emanate from MO for a successful CE process in overall benefit for firms and the economy. The overall philosophy of looking at future market needs and customer demands requires a breakthrough in the current century in lines with Schumpeter's one in the last century. As of today, the Schumpeterian idea seems more relevant to opportunity recognition. Ideas are like products that must obsolete with time to move ahead. There seems space for arguments, ideas, and philosophies that could bring more relevant products and services in the market by exploiting the gaps timely due to the natural obsolescence of products and services.

\section{Abbreviations}

Creative destruction (CD)

Technical opportunity (TO)

Market orientation (MO)

Structural Equation Modeling (SEM)

Partial Least Square (PLS)

\section{Declarations}

\section{Availability of data and material}

The datasets used and/or analysed during the current study are available from the corresponding author on reasonable request.

\section{Competing interests}

The authors do not have any competing/ conflicting interests to declare as regard to this research study.

\section{Funding}

No funding has been provided for carrying out this research study.

\section{Authors contributions}

MZA conceived the study and carried out literature review. Research design was finalized after approval of SK. AP carried out statistical analysis and finalized the findings of the study. MZA had written introduction, discussion and conclusions of the study. MRU and MZA jointly carried out data collection. 
AP and SK coordinated institutional supports to assist data collection, overall supervised the study and approved the write-up. All authors read and approved the final manuscript.

\section{Acknowledgements}

The authors acknowledge the support extended by The Superior University, Pakistan in provision of supervisory support, whenever required, during all phases of research study.

\section{References}

1. Ahmed, N. O. A. (2016). Relationship between innovation climate, market orientation and corporate entrepreneurship. International Review of Management and Marketing, 6(3), 476-480.

2. Alam, M. Z., Bilal, A. R., Sabir, S., \& Kaleem, M. A. (2020). Role of engineering major in entrepreneurial intentions of engineering students: a case of Pakistan. Education+ Training. 62(7/8), 965-978. doi:10.1108/ET-06-2019-0134.

3. Alam, M. Z., Kousar, S., \& Rehman, C. A. (2019). Role of entrepreneurial motivation on entrepreneurial intentions and behaviour: theory of planned behaviour extension on engineering students in Pakistan. Journal of Global Entrepreneurship Research, 9(1), 1-20. doi:10.1186/s40497-019-0175-1.

4. Alam, M. Z., Kousar, S., Shabbir, A., \& Kaleem, M. A. (2020). Personality traits and intrapreneurial behaviour. Asia Pacific Journal of Innovation and Entrepreneurship. 14(1). 31-46. doi:10.1108/APJIE09-2019-0068.

5. Alsos, Gry Agnete and Kaikkonen, Virpi, Opportunities and Prior Knowledge: A Study of Experienced Entrepreneurs (2006). Babson College, Babson Kauffman Entrepreneurship Research Conference (BKERC), 2002-2006, Available at SSRN: https://ssrn.com/abstract=1768092.

6. Amit, R., Glosten, L., \& Muller, E. (1993). Challenges to theory development in entrepreneurship research. Journal of Management Studies, 30(5), 815-834.

7. Amore, M. D., Schneider, C., \& Žaldokas, A. (2013). Credit supply and corporate innovation. Journal of Financial Economics, 109(3), 835-855.

8. Antoncic, B., \& Hisrich, R. D. (2001). Intrapreneurship: Construct refinement and cross-cultural validation. Journal of Business Venturing, 16(5), 495-527.

9. Ardichvili, A., Cardozo, R., \& Ray, S. (2003). A theory of entrepreneurial opportunity identification and development. Journal of Business Venturing, 18(1), 105-123.

10. Atuahene-Gima, K., Slater, S. F., \& Olson, E. M. (2005). The contingent value of responsive and proactive market orientations for new product program performance. Journal of Product Innovation Management, 22(6), 464-482.

11. Bai, W., Holmström Lind, C., \& Johanson, M. (2016). The performance of international returnee ventures: the role of networking capability and the usefulness of international business knowledge. Entrepreneurship \& Regional Development, 28(9-10), 657-680. 
12. Baker, W. E., \& Sinkula, J. M. (2009). The complementary effects of market orientation and entrepreneurial orientation on profitability in small businesses. Journal of Small Business Management, 47(4), 443-464.

13. Barney, J. (1991). Firm resources and sustained competitive advantage. Journal of Management, 17(1), 99-120.

14. Barrett, H., Balloun, J. L., \& Weinstein, A. (2012). Creative climate: a critical success factor for $21 \mathrm{st}$ century organisations. International Journal of Business Innovation and Research, 6(2), 202-219.

15. Barrett H., Weinstein A. (2015) Corporate Entrepreneurship, The Marketing Mix, and Business Performance. In: Wilson E., Hair, Jr. J. (eds) Proceedings of the 1997 Academy of Marketing Science (AMS) Annual Conference. Developments in Marketing Science: Proceedings of the Academy of Marketing Science. Springer, Cham. https://doi.org/10.1007/978-3-319-13141-2_61

16. Barringer, B. R., \& Bluedorn, A. C. (1999). The relationship between corporate entrepreneurship and strategic management. Strategic Management Journal, 20(5), 421-444.

17. Bennett, R. C., \& Cooper, R. G. (1979). Beyond the marketing concept. Business Horizons, 22(3), 7683.

18. Bennett, R. C., \& Cooper, R. G. (1981). The misuse of marketing: an American tragedy. Business Horizons, 24(6), 51-61.

19. Bhide, A. (2003). The origin and evolution of new businesses. Oxford University Press.

20. Blau, D. M. (1987). A time-series analysis of self-employment in the United States. Journal of Political Economy, 95(3), 445-467.

21. Blaug, M. (2000). Entrepreneurship before and after Schumpeter. Entrepreneurship: The Social Science View, 12(1), 76-88.

22. Bojica, A. M., del Mar Fuentes, M., \& Gómez-Gras, J. M. (2011). Radical and incremental entrepreneurial orientation: The effect of knowledge acquisition. Journal of Management \& Organization, 17(3), 326-343.

23. Buenstorf, G. (2007). Creation and pursuit of entrepreneurial opportunities: An evolutionary economics perspective. Small Business Economics, 28(4), 323-337.

24. Casson, M. (1995). Entrepreneurship and business culture(Vol. 1). Edward Elgar Publishing.

25. Chandler, Gaylen N. and DeTienne, Dawn R. and Lyon, Douglas W., Outcome Implications of Opportunity Creation / Discovery Processes (2003). Babson College, Babson Kauffman Entrepreneurship Research Conference (BKERC), 2002-2006, Available at SSRN: https://ssrn.com/abstract=1783698.

26. Chin, W. W. (1998). The partial least squares approach to structural equation modeling. Modern Methods for Business Research, 295(2), 295-336.

27. Chin, W. W., \& Newsted, P. R. (1999). Structural equation modeling analysis with small samples using partial least squares. Statistical Strategies for Small Sample research, 1(1), 307-341. 
28. Choi, Y. R., Lévesque, M., \& Shepherd, D. A. (2008). When should entrepreneurs expedite or delay opportunity exploitation? Journal of Business Venturing, 23(3), 333-355.

29. Chung, L. H., \& Gibbons, P. T. (1997). Corporate entrepreneurship: The roles of ideology and social capital. Group \& Organization Management, 22(1), 10-30.

30. Companys, Y. E., \& McMullen, J. S. (2007). Strategic entrepreneurs at work: The nature, discovery, and exploitation of entrepreneurial opportunities. Small Business Economics, 28(4), 301-322.

31. Covin, J. G., \& Slevin, D. P. (1991). A conceptual model of entrepreneurship as firm behavior. Entrepreneurship Theory and Practice, 16(1), 7-26.

32. Dimov, Dimo, The Nexus of Individual and Opportunity: Opportunity Recognition as a Learning Process (2003). Babson College, Babson Kauffman Entrepreneurship Research Conference (BKERC), 2002-2006, Available at SSRN: https://ssrn.com/abstract=1783742

33. Drucker, P. (1985). Innovation and entrepreneurship: principles and practices. HarperTrade.

34. Drucker, P. (1998). The Discipline of innovation. Harvard Business Review.

35. Drucker, P. F. (2007). Management challenges for the 21st century. Routledge.

36. Echols, A. E., \& Neck, C. P. (1998). The impact of behaviors and structure on corporate entrepreneurial success. Journal of Managerial Psychology. 13(1/2), 38-46. doi:10.1108/02683949810369110.

37. Eckhardt, J. T., \& Shane, S. A. (2003). Opportunities and entrepreneurship. Journal of Management, 29(3), 333-349.

38. Fornell, C., \& Larcker, D. F. (1981). Evaluating structural equation models with unobservable variables and measurement error. Journal of Marketing Research, 18(1), 39-50.

39. Gaglio, C. M., \& Katz, J. A. (2001). The psychological basis of opportunity identification: Entrepreneurial alertness. Small Business Economics, 16(2), 95-111.

40. García-Morales, V. J., Bolívar-Ramos, M. T., \& Martín-Rojas, R. (2014). Technological variables and absorptive capacity's influence on performance through corporate entrepreneurship. Journal of Business Research, 67(7), 1468-1477.

41. González-Benito, Ó., González-Benito, J., \& Muñoz-Gallego, P. A. (2009). Role of entrepreneurship and market orientation in firms' success. European Journal of Marketing. 43(3/4), 500-522. doi:10.1108/03090560910935550.

42. Goodale, J. C., Kuratko, D. F., Hornsby, J. S., \& Covin, J. G. (2011). Operations management and corporate entrepreneurship: The moderating effect of operations control on the antecedents of corporate entrepreneurial activity in relation to innovation performance. Journal of Operations Management, 29(1-2), 116-127.

43. Goosen, C., Smit, E. d. M., \& De Coning, T. (2002). The development of a factor based instrument to measure corporate entrepreneurship: A South African perspective. South African Journal of Business Management, 33(3), 39-51.

44. Guth, W. D., \& Ginsberg, A. (1990). Guest editors' introduction: Corporate entrepreneurship. Strategic Management Journal, 11(Special Issue), 5-15. 
45. Hair, J. F., Ringle, C. M., Gudergan, S. P., Fischer, A., Nitzl, C., \& Menictas, C. (2019). Partial least squares structural equation modeling-based discrete choice modeling: an illustration in modeling retailer choice. Business Research, 12(1), 115-142. doi:10.1007/s40685-018-0072-4.

46. Hanusch, H., \& Pyka, A. (2007). Elgar companion to neo-Schumpeterian economics. Edward Elgar Publishing.

47. Hayek, F. A. (1945). The use of knowledge in society. The American Economic Review, 35(4), 519530.

48. Henseler, J., Ringle, C. M., \& Sarstedt, M. (2015). A new criterion for assessing discriminant validity in variance-based structural equation modeling. Journal of the Academy of Marketing Science, 43(1), 115-135.

49. Hornsby, J. S., Kuratko, D. F., \& Zahra, S. A. (2002). Middle managers' perception of the internal environment for corporate entrepreneurship: assessing a measurement scale. Journal of Business Venturing, 17(3), 253-273.

50. Ireland, R. D., Covin, J. G., \& Kuratko, D. F. (2009). Conceptualizing corporate entrepreneurship strategy. Entrepreneurship Theory and Practice, 33(1), 19-46. doi:10.1111/j.1540-6520.2008.00279.x.

51. Jaworski, B. J., \& Kohli, A. K. (1996). Market orientation: review, refinement, and roadmap. Journal of Market-Focused Management, 1(2), 119-135.

52. Jennings, D. F., \& Lumpkin, J. R. (1989). Functioning modeling corporate entrepreneurship: An empirical integrative analysis. Journal of Management, 15(3), 485-502.

53. Karlin, B. E., Ruzek, J. I., Chard, K. M., Eftekhari, A., Monson, C. M., Hembree, E. A., Resick, P. A., \& Foa, E. B. (2010). Dissemination of evidence-based psychological treatments for posttraumatic stress disorder in the Veterans Health Administration. Journal of Traumatic Stress, 23(6), 663-673.

54. Kerby, J. K. (1972). The marketing concept: Suitable guide to product strategy. Business Quarterly, $37(2), 31-35$.

55. Kirzner, I. M. (1997). Entrepreneurial discovery and the competitive market process: An Austrian approach. Journal of Economic Literature, 35(1), 60-85.

56. Kock, N. (2015). Common method bias in PLS-SEM: A full collinearity assessment approach. International Journal of e-Collaboration, 11(4), 1-10.

57. Kohli, A. K., \& Jaworski, B. J. (1990). Market orientation: the construct, research propositions, and managerial implications. Journal of Marketing, 54(2), 1-18.

58. Krueger Jr, N. F., Reilly, M. D., \& Carsrud, A. L. (2000). Competing models of entrepreneurial intentions. Journal of Business Venturing, 15(5-6), 411-432.

59. Lee, J.-H., \& Venkataraman, S. (2006). Aspirations, market offerings, and the pursuit of entrepreneurial opportunities. Journal of Business Venturing, 21(1), 107-123.

60. Lee, J., \& Pati, N. (2017). A study of the effect of corporate diversification strategy on technological innovation and strength in technology-oriented multinational corporations across countries. International Journal of Business Innovation and Research, 13(1), 1-29. 
61. MacDonald, S. (1995). Too close for comfort?: The strategic implications of getting close to the customer. California Management Review, 37(4), 8-27.

62. MacKinnon, D. P., Lockwood, C. M., \& Williams, J. (2004). Confidence limits for the indirect effect: Distribution of the product and resampling methods. Multivariate behavioral research, 39(1), 99-128.

63. Meyer, G. D., \& Heppard, K. A. (2000). Entrepreneurship as strategy: Competing on the entrepreneurial edge. Sage Publications.

64. Munir, H., Jianfeng, C., \& Ramzan, S. (2019). Personality traits and theory of planned behavior comparison of entrepreneurial intentions between an emerging economy and a developing country. International Journal of Entrepreneurial Behavior \& Research, 25(3), 554-580. doi:10.1108/IJEBR-052018-0336

65. Narver, J. C., \& Slater, S. F. (1990). The effect of a market orientation on business profitability. Journal of Marketing, 54(4), 20-35.

66. Park, J. Y., Sung, C. S., \& Im, I. (2017). Does social media use influence entrepreneurial opportunity? A review of its moderating role. Sustainability, 9(9), 1-16.

67. Pech, R. J., \& Cameron, A. (2006). An entrepreneurial decision process model describing opportunity recognition. European Journal of Innovation Management. 9(1), 61-78.

doi:10.1108/14601060610640023.

68. Renko, M., Carsrud, A., \& Brännback, M. (2009). The effect of a market orientation, entrepreneurial orientation, and technological capability on innovativeness: A study of young biotechnology ventures in the United States and in Scandinavia. Journal of Small Business Management, 47(3), 331-369.

69. Rutherford, M. W., \& Holt, D. T. (2007). Corporate entrepreneurship: An empirical look the innovativeness dimension and its antecedents. Journal of Organizational Change Management, 20(3), 429-446.

70. Sambasivan, M., Abdul, M., \& Yusop, Y. (2009). Impact of personal qualities and management skills of entrepreneurs on venture performance in Malaysia: Opportunity recognition skills as a mediating factor. Technovation, 29(11), 798-805.

71. Saraf, N., Langdon, C. S., \& Gosain, S. (2007). IS application capabilities and relational value in interfirm partnerships. Information Systems Research, 18(3), 320-339.

72. Sarasvathy, S. D., Dew, N., Velamuri, S. R., \& Venkataraman, S. (2010). Three views of entrepreneurial opportunity. In Handbook of entrepreneurship research (pp. 77-96). Springer.

73. Sarstedt, M., Ringle, C.M., Smith, D., Reams, R. and Hair, J.F. Jr. (2014). Partial least squares structural equation modeling (PLS-SEM): a useful tool for family business researchers. Journal of Family Business Strategy, 5(1), 105-115. doi:10.1016/j.jfbs.2014.01.002.

74. Schumpeter, J. (1934). The theory of economic development. Harvard University Press.

75. Schumpeter, J., \& Backhaus, U. (2003). The theory of economic development. In Joseph Alois Schumpeter (pp. 61-116). Springer.

76. Schumpeter, J. A. (2013). Capitalism, socialism and democracy. Routledge. 
77. Schumpeter, J. A., \& Redvers, O. (1961). The Theory of Economic Development... Translated by Redvers Opie.[A Reduced Photographic Reprint of the Edition of 1934.]. Oxford University Press.

78. Sciascia, S., Naldi, L., \& Hunter, E. (2006). Market orientation as determinant of entrepreneurship: An empirical investigation on SMEs. The International Entrepreneurship and Management Journal, 2(1), 21-38.

79. Shane, S. (2012). Reflections on the 2010 AMR decade award: Delivering on the promise of entrepreneurship as a field of research. Academy of Management Review, 37(1), 10-20.

80. Shane, S., \& Venkataraman, S. (2000). The promise of entrepreneurship as a field of research. Academy of Management Review, 25(1), 217-226.

81. Shane, S. A. (2003). A general theory of entrepreneurship: The individual-opportunity nexus. Edward Elgar Publishing.

82. Shepherd, D. A., \& DeTienne, D. R. (2005). Prior knowledge, potential financial reward, and opportunity identification. Entrepreneurship Theory and Practice, 29(1), 91-112.

83. Shrout, P. E., \& Bolger, N. (2002). Mediation in experimental and nonexperimental studies: new procedures and recommendations. Psychological Methods, 7(4), 422-445.

84. Singh, R. P. (2000). Entrepreneurial opportunity recognition through social networks. Psychology Press.

85. Slater, S. F., \& Narver, J. C. (1994). Does competitive environment moderate the market orientationperformance relationship? Journal of Marketing, 58(1), 46-55.

86. Tian, X., \& Wang, T. Y. (2014). Tolerance for failure and corporate innovation. The Review of Financial Studies, 27(1), 211-255.

87. Williams, D. W., \& Wood, M. S. (2015). Rule-based reasoning for understanding opportunity evaluation. Academy of Management Perspectives, 29(2), 218-236.

88. Wilson, J. (2014). Essentials of business research: A guide to doing your research project. Sage.

89. Witt, U., \& Foster, J. (1992). Turning Austrian economics into an evolutionary theory. In Austrian economics: Tensions and new directions (pp. 215-243). Springer.

90. Woo, H. R. (2018). Personality traits and intrapreneurship: the mediating effect of career adaptability. Career Development International, 23(2), 145-162. doi:10.1108/CDI-02-2017-0046.

91. Zachary, M. A., McKenny, A., Short, J. C., \& Payne, G. T. (2011). Family business and market orientation: Construct validation and comparative analysis. Family Business Review, 24(3), 233-251.

92. Zahra, S. A., Nielsen, A. P., \& Bogner, W. C. (1999). Corporate entrepreneurship, knowledge, and competence development. Entrepreneurship Theory and Practice, 23(3), 169-189.

93. Zampetakis, L. A., \& Moustakis, V. S. (2010). An exploratory research on the factors stimulating corporate entrepreneurship in the Greek public sector. International Journal of Manpower. 31(8), 871887. doi:10.1108/01437721011088557.

94. Zimmerman, J. (2010). Corporate entrepreneurship at GE and Intel. Journal of Business Case Studies, 6(5), 77-82. doi:10.19030/jbcs.v6i5.902. 
95. Zortea-Johnston, E., Darroch, J., \& Matear, S. (2012). Business orientations and innovation in small and medium sized enterprises. International Entrepreneurship and Management Journal, 8(2), 145164.

\section{Figures}

\section{Providing Novelty}

- New methods of production

- New solutions
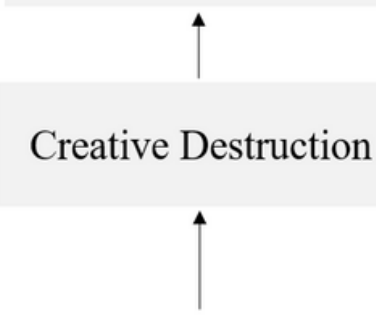

Encourage

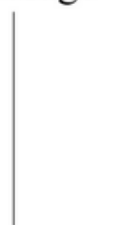

\section{Degree of novelty}

- Change style

- Product improvement

- New product

- Major innovations

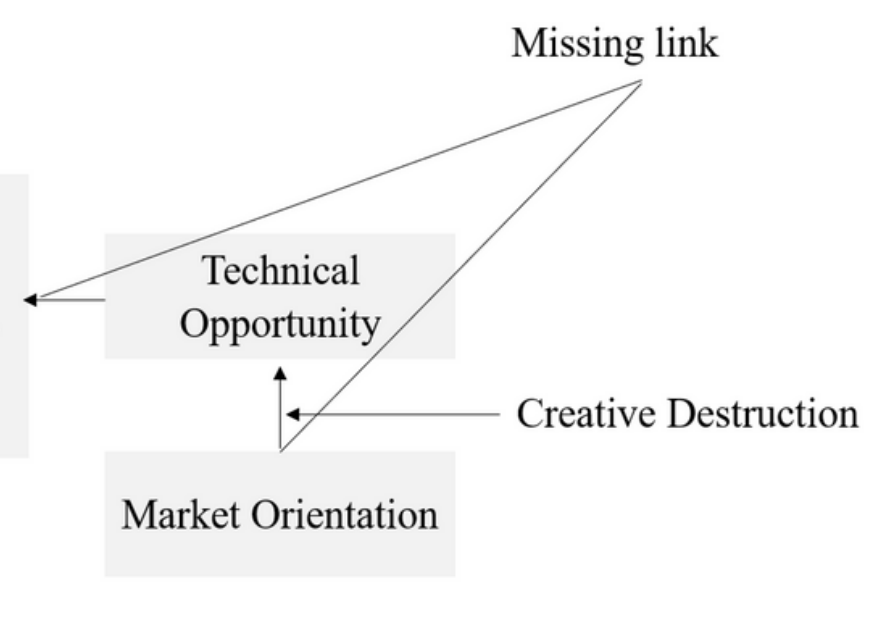

- New opportunities

- Recourse acquisition

- Implementation, exploitation and commercialization of opportunities

Examine

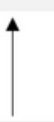

Attitudes and Actions

|

Corporate Entrepreneurship

\section{Figure 1}

The missing link between $\mathrm{TO}, \mathrm{MO}, \mathrm{CD}$, and $\mathrm{CE}$

\section{Creative destruction}

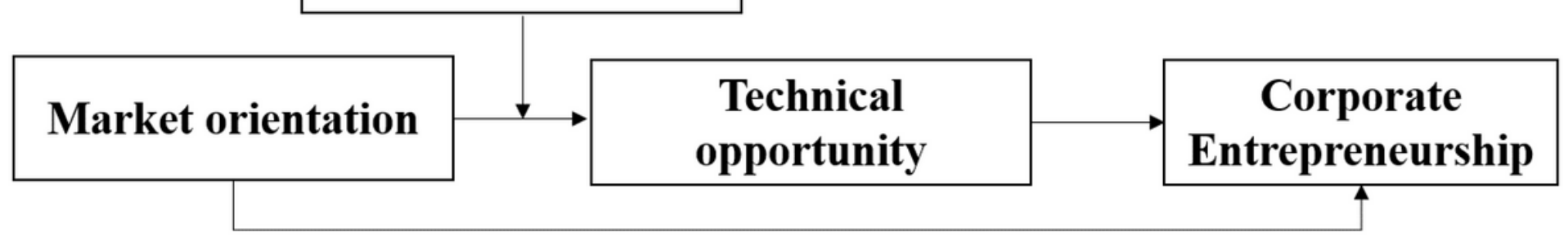

Figure 2 


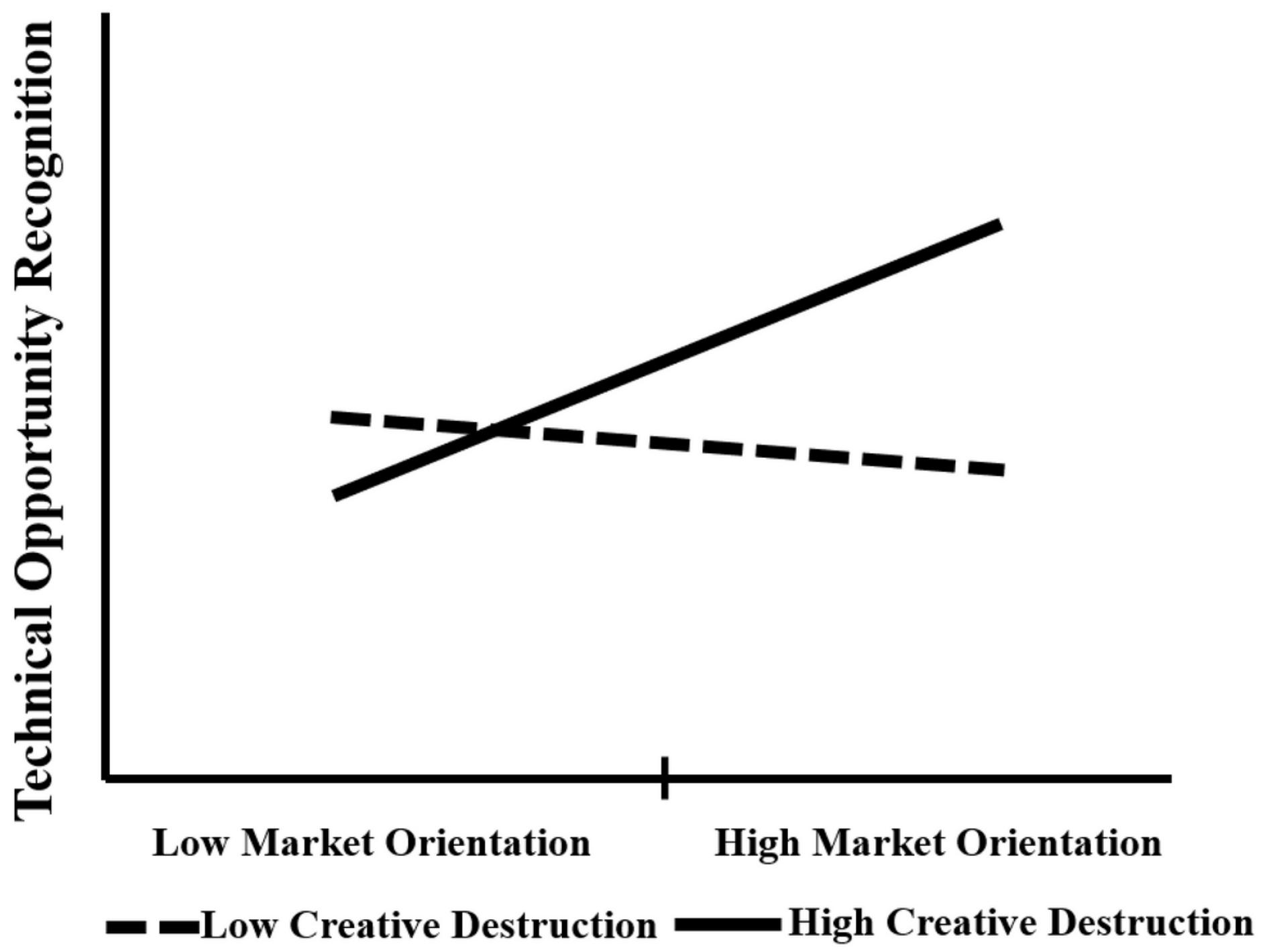

Figure 3

Moderating effect of $\mathrm{CD}$ on $\mathrm{MO}$ and $\mathrm{TO}$ 